\title{
Calcined Clay Pozzolan as an Admixture to Mitigate the Alkali-Silica Reaction in Concrete
}

\author{
James Sarfo-Ansah ${ }^{1}$, Eugene Atiemoํㅜ, Kwabena Appiah Boakye1, Delali Adjei, \\ Albert A. Adjaottor ${ }^{2}$ \\ ${ }^{1}$ Building Material Development Division, Building and Roads Research Institute, \\ Council for Scientific and Industrial Research, Kumasi, Ghana \\ ${ }^{2}$ Department of Materials Science and Engineering, Kwame Nkrumah University of Science and Technology, \\ Kumasi, Ghana \\ Email: ${ }^{*}$ abeefo@yahoo.com
}

Received 20 March 2014; revised 18 April 2014; accepted 8 May 2014

Copyright (C) 2014 by authors and Scientific Research Publishing Inc.

This work is licensed under the Creative Commons Attribution International License (CC BY). http://creativecommons.org/licenses/by/4.0/

(c) (i) Open Access

\begin{abstract}
Calcined clay pozzolan has been used to replace varying portions of high alkali Portland limestone cement in order to study its effect on the alkali-silica reaction (ASR). Portland limestone cement used for the study had a total $\mathrm{Na}_{2} \mathrm{O}_{\text {eq }}$ of 4.32. Mortar-bar expansion decreased as pozzolan content in the cement increased. The highest expansion was recorded for reference bars with no pozzolan, reaching a maximum of $0.35 \%$ at 42 days whilst the expansion was reduced by between $42.5 \%$ and $107.8 \%$ at 14 days and between $9.4 \%$ and $16.4 \%$ at 84 days with increasing calcined clay pozzolan content. Mortar bars with $25 \%$ pozzolan were the least expansive recording expansion less than $0.1 \%$ at all test ages. $X$-ray diffractometry of the hydrated blended cement paste powders showed the formation of stable calcium silicates in increasing quantities whilst the presence of expansive alkali-silica gel, responsible for ASR expansion, decreased as pozzolan content increased. The study confirms that calcined clay pozzolan has an influence on ASR in mortar bars and causes a significant reduction in expansion at a replacement level of $25 \%$.
\end{abstract}

\section{Keywords}

Calcined Clay Pozzolan, Alkali-Silica Reaction, Expansion, Sodium Silicate gel, Calcium Silicates

\footnotetext{
${ }^{*}$ Corresponding author.
} 


\section{Introduction}

The alkali-silica reaction (ASR) is a chemical reaction within concrete between reactive siliceous constituents of coarse aggregates and the alkali hydroxides released during the hydration of a high alkali Portland cement, with an alkali content of over $0.6 \%$ [1], in the presence of sufficient moisture [2] [3]. The reaction products of ASR are normally alkali-silicate gel or even crystalline products which display a variable capacity for swelling caused by the absorption of further moisture. Such swelling within hardened concrete can cause cracking and overall expansion [4] [5]. ASR is often only apparent under field conditions after 5 to 15 years and can cause serious damage to any concrete structure [6] but accelerated methods are available to rapidly determine the reactivity or otherwise of aggregates [7]-[9].

Kandasamy and Shehata [10] evaluated the effect of high calcium fly ash/slag ternary blended cements on ASR by both the accelerated mortar bar method of ASTM C 1260 [8] and the 2-year concrete prism test prescribed by Canadian standard CSA A 23.2-14A/28A [11]. They observed a good agreement between the results of the two test methods and concluded that ASTM C 1260 provided a conservative evaluation of the ability of the supplementary cementitious materials studied to mitigate ASR.

Where high alkali cement and/or reactive aggregates must be used due to the absence of innocuous aggregates, the use of mineral admixtures is recommended to inhibit the occurrence of ASR. Mineral admixtures recommended include ground granulated blast furnace slag (GGBS), silica fume, metakaolin and natural or artificial pozzolans such as zeolites and fly ash [6] [12]-[14]. Fly ash would inhibit ASR when its content in cement is larger than $25 \%$ [13].

Metakaolin and calcined clay are effective pozzolanic materials in suppressing alkali-silica reaction and this is attributed to refined pore structure thus reducing ionic mobility, consumption of calcium hydroxide, and entrapment of alkalis in silica rich hydration products [13] [15]. Reduction in alkalinity (and associated pH) in the pore solution and depletion of portlandite are considered as the most beneficial effects of pozzolans in reducing expansion due to alkali-silica reaction (ASR). In light of this, the potential for using metakaolin to control alkali-silica expansion in concrete has been reported by Walters [16] and Kostuch et al. [17].

Alkali content in Portland cement is increasingly becoming higher than the stipulated safe limit of $1.0 \%$ due to the use of early strength enhancers in current global production trends [9]. In addition, EN standard [18] recommends incorporation of 5\% - 25\% limestone in cement and most aggregates are not tested for potential reactivity per international standards [19] [20]. Hence there is the need to investigate possible admixtures which can be incorporated in concrete to forestall damage of structures due to ASR. This research investigates the effectiveness of calcined clay pozzolan in controlling ASR in cement by substituting $0 \%-30 \%$ of high alkali PLC with calcined clay pozzolan.

\section{Materials and Methods}

Calcined clay pozzolan, produced by CSIR-BRRI, class 32.5R Portland limestone cement (PLC) manufactured by Ghana Cement Company Limited (GHACEM) were used for the research. To satisfy the conditions for the occurrence of ASR, silica glass, a known reactive aggregate [21] [22], obtained from crushed pyrex laboratory glassware were used for the research. Particle size of the silica glass ranged between $0.15-0.60 \mathrm{~mm}$. The chemical composition of the pozzolan and PLC were evaluated using a SpectroXlab 2000 X-Ray Fluorescence spectrophotometer. Bulk densities of the pozzolan and PLC were determined according to methods in BS 1377 [23] whilst the respective Blaine indices were obtained according to ASTM C 204 [24].

A modified form of ASTM C 1260 was used for the experiment. The calcined clay pozzolan was used to replace between $0 \%$ and $30 \%$ of the PLC for the test. Total cement to aggregate ratio of 1:3 was used in forming mortar bars of size $25 \mathrm{~mm} \times 25 \mathrm{~mm} \times 285 \mathrm{~mm}$ using water to cement ratio of 0.5 instead of the specified 0.47 to cater for workability of the pozzolan cement mortar. Three mortar bars were moulded for each specimen of mortar mix. Mortar bars were initially stored in a moist cabinet for $24 \mathrm{~h}$ as specified in ASTM C 1260. However, after initial length readings were taken, the specimens were further cured for 27 days in water at $20^{\circ} \mathrm{C}$ to enable the pozzolanic reaction proceed to an appreciable rate. The bars were further cured in water at $80^{\circ} \mathrm{C}$ for $24 \mathrm{~h}$ after which zero readings of the bars were measured using a length comparator recommended in ASTM C 490 [25]. After taking the initial lengths, the bars were placed in $1 \mathrm{~N} \mathrm{NaOH}$ solution at $80^{\circ} \mathrm{C}$ and subsequent lengths measurements were taken at 14, 42, 56 and 84 days. After 84 days, samples of some bars were treated with acetone to stop hydration and ground for XRD analysis using a PHILLIPS PW1830 diffractometer. The morpholo- 
gy of the hydrated samples was also studied with an Olympus BX 41 TF optical microscope.

\section{Results and Discussion}

\subsection{Physical and Chemical Evaluation}

Figure 1 shows an XRD graph pattern of the clay sample. The main clay minerals identified in the clay were kaolinite and chlorite with rock-forming minerals in the form of quartz and goethite. The pozzolan used had a bulk density of $953 \mathrm{~kg} / \mathrm{m}^{3}$ and a Blaine index of $892 \mathrm{~m}^{2} / \mathrm{kg}$. The Blaine index of the PLC was $352 \mathrm{~m}^{2} / \mathrm{kg}$. Figure 2 shows the particle size distribution of the pozzolan.

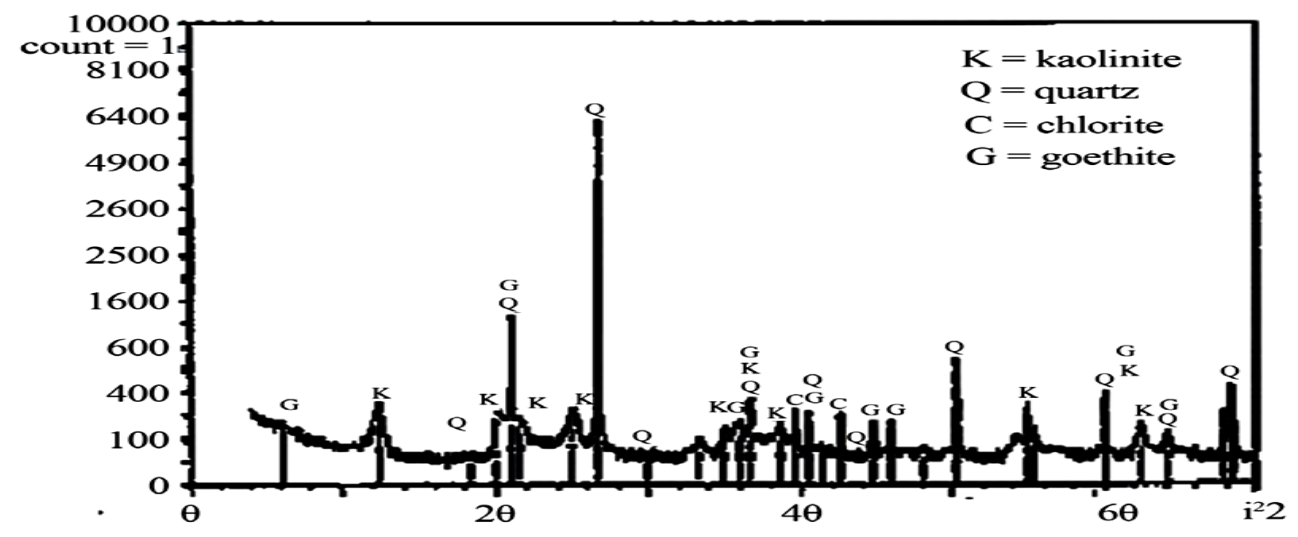

Figure 1. XRD image of Mankranso clay.

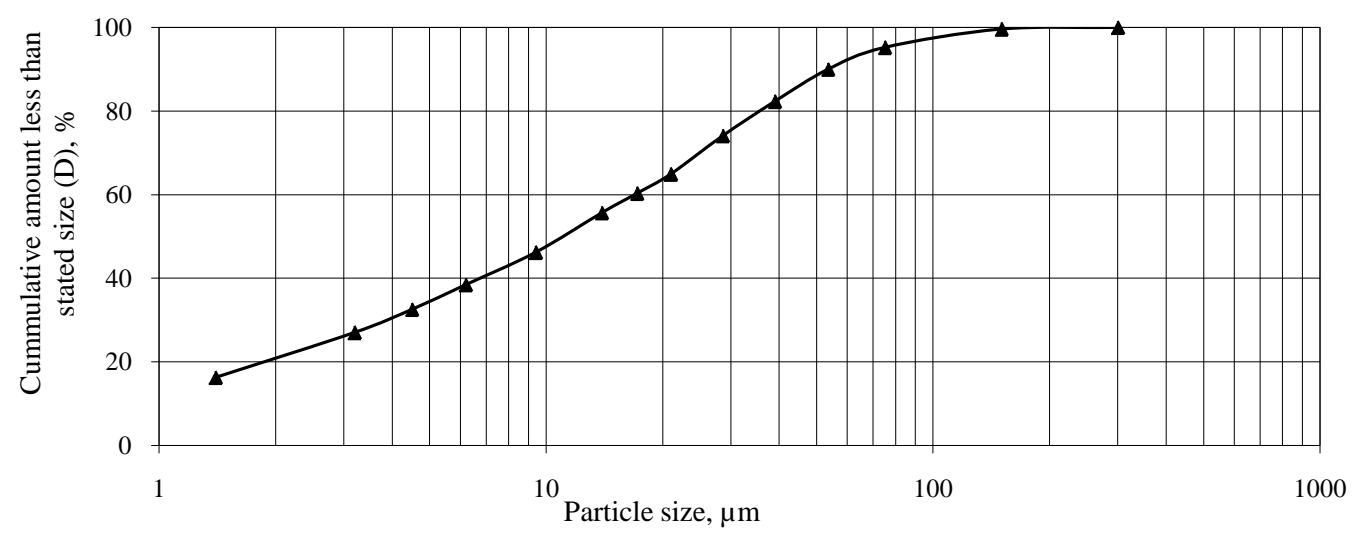

Figure 2. Particle size distribution of pozzolan sample.

About $60 \%$ of the pozzolan had particle size less than $20 \mu \mathrm{m}$. Thus the pozzolan had a high percentage of fines which would promote densification of the mortar prisms and also react quickly to help inhibit the alkali silica reaction. Table 1 shows that the $\mathrm{Na}_{2} \mathrm{Oeq}$ of the clay pozzolan was $0.62 \%$ whilst that of the PLC was $4.32 \%$. The $\mathrm{SiO}_{2}$ content of $62 \%$ the pozzolan exceeded the standard minimum limit of $25.0 \%$ and the sum of $\mathrm{SiO}_{2}, \mathrm{Al}_{2} \mathrm{O}_{3}$ and $\mathrm{Fe}_{2} \mathrm{O}_{3}$ also exceeded the minimum value of $70 \%$ [26]. Thus the material was chemically suitable as a pozzolan.

Table 1. Chemical composition of pozzolan and PLC.

\begin{tabular}{ccccccc}
\hline & \multicolumn{5}{c}{ Composition, \% } \\
\cline { 2 - 7 } Sample & $\mathrm{SiO}_{2}$ & $\mathrm{Al}_{2} \mathrm{O}_{3}$ & $\mathrm{Fe}_{2} \mathrm{O}_{3}$ & $\mathrm{CaO}$ & $\mathrm{SO}_{3}$ & $\mathrm{Na}_{2} \mathrm{Oeq}$ \\
\hline Pozzolan & 62 & 16.7 & 13 & 0.2 & 0.2 & 0.62 \\
PLC & 19.7 & 4 & 3.2 & 62 & 1.8 & 4.3 \\
\hline
\end{tabular}




\subsection{Mortar Bar Expansion}

Figure 3 shows the expansion of the mortar bars incorporating different percentages of calcined clay pozzolan. The reference bars had high expansion, reaching a maximum length of $0.35 \%$ at 42 days. Thereafter, expansion of the reference bars slowed down marginally; probably signaling an end of swelling of alkali-silicate gel formed. Incorporating $10 \%$ clay pozzolan showed high expansion but below that of the reference sample. Up to 14 days, all mortar bars incorporating calcined clay pozzolan expanded significantly lower than the reference bars. Samples with $25 \%$ and $30 \%$ clay pozzolan showed the least expansion followed by the bars containing $15 \%$, $20 \%$ and $10 \%$ pozzolan respectively. However, after 28 days storage in $1 \mathrm{~N} \mathrm{NaOH}$, the difference in expansion between the reference and mortar bars incorporating $10 \%$ and $15 \%$ pozzolan reduced. The highest reduction in expansion for $10 \%$ and $15 \%$ pozzolan cement mortar bars was $45 \%$ at 28 days. However, there was at least a $70 \%$ reduction in expansion in mortar bars containing $20 \%-30 \%$ pozzolan. Steady gains in expansion were recorded for pozzolan cement mortar bars up to 84 days with bars containing $25 \%$ pozzolan having the least expansion of $0.05 \%$ at 84 days.

\subsection{Hydration Products and Surface Examination}

Figure 4 shows XRD patterns of the hydrated cement samples after 84 days. Prominent products identified were tobermorite $\left[\mathrm{Ca}_{5} \mathrm{Si}_{6} \mathrm{O}_{16}(\mathrm{OH})_{2}\right]$, Portlandite, $\mathrm{Ca}(\mathrm{OH})_{2}, \mathrm{CaSi}_{2} \mathrm{O}_{5}$ and sodium silicate $\left(\mathrm{Na}_{2} \mathrm{Si}_{2} \mathrm{O}_{5} \cdot \mathrm{nH}_{2} \mathrm{O}\right)$. As the content of pozzolan increased from $0 \%$ to $30 \%$, the occurrence of a calcium silicate, $\mathrm{CaSi}_{2} \mathrm{O}_{5}$, other than tobermorite, is observed. There is a decrease in the content of sodium silicate and portlandite progressively as pozzolan content increases. The $\mathrm{CaSi}_{2} \mathrm{O}_{5}$ formed is more stable than the sodium silicate, is not susceptible to swelling and therefore helps to reduce expansion. The results agree with the postulates of Ichikawa [27] who predicts the consumption of $\mathrm{Ca}(\mathrm{OH})_{2}$, leading to the formation of mature calcium silicates in a pozzolanic reaction, which fill the micro pores of concrete containing pozzolans and thus help inhibit ASR.

The results also agree with earlier results with fly ash and other pozzolans [4] [10] in which the substitution of calcium ions with alkali ions $\left(\mathrm{Na}^{+}\right)$and thus the formation of alkali silicate gel were identified as the agent responsible for expansion.

Figure 5 and Figure 6 show the surfaces of reference bar and that containing 25\% pozzolan. Whereas excessive expansion led to cracks on the surface of the mortar bar with no pozzolan, it is observed that the effect of alkali on the surfaces of mortar bars containing $25 \%$ pozzolan is minimized. The pozzolanic reaction between the

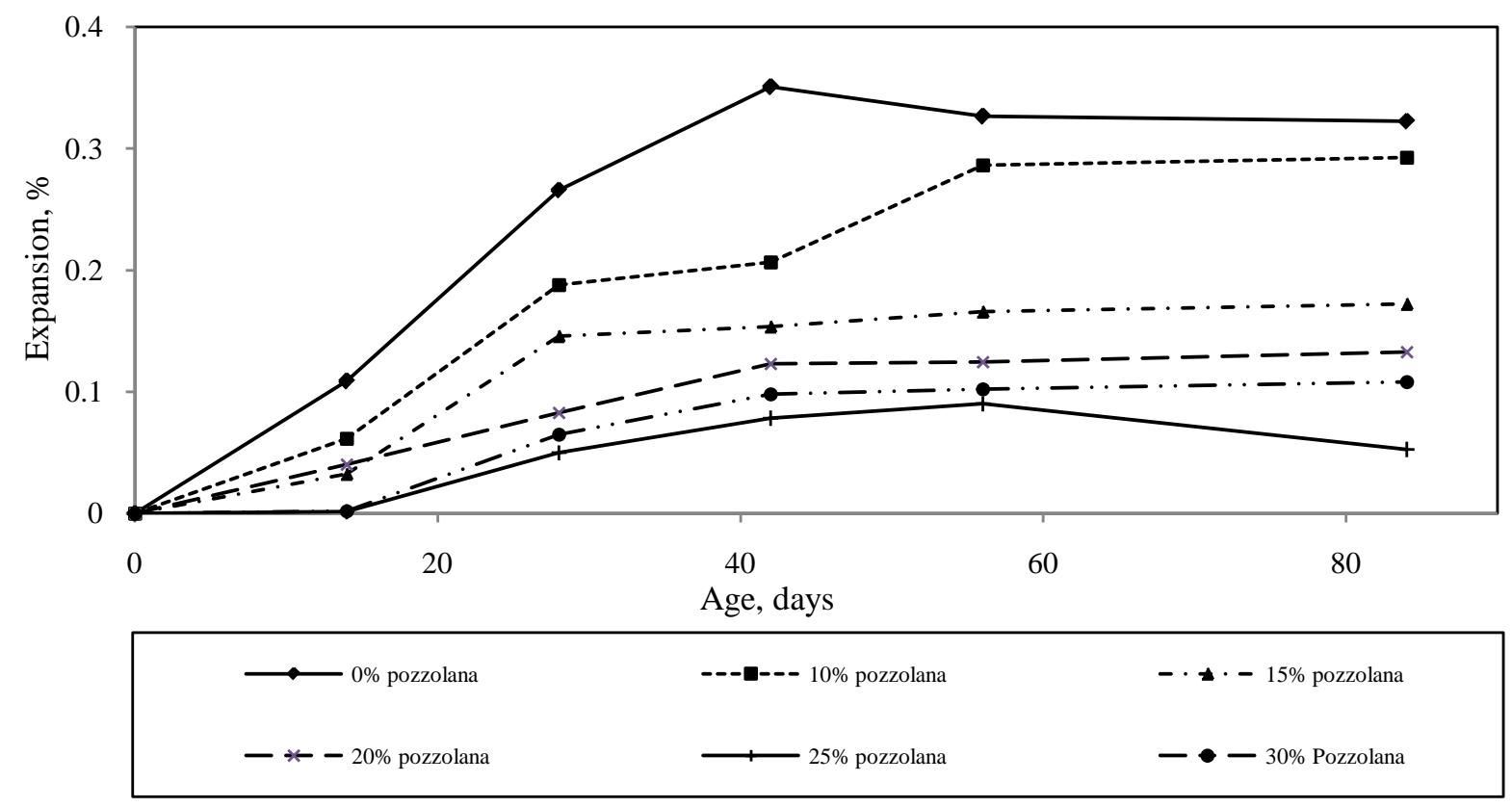

Figure 3. Expansion of different pozzolan cement mortar bars with time. 

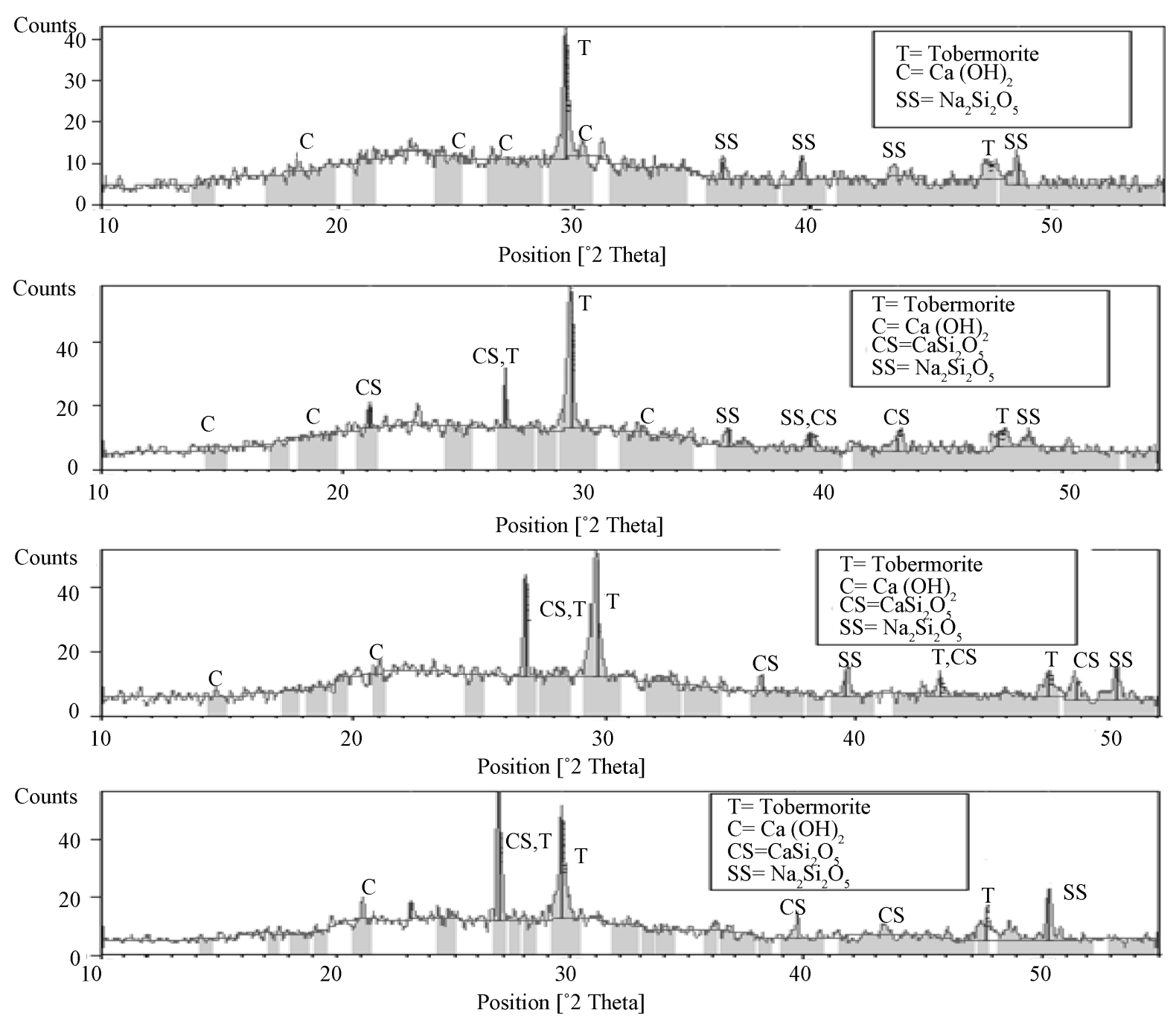

Figure 4. XRD images of hydrated pastes containing $0 \%, 10 \%, 20 \%$ and $25 \%$ pozzolan (top to bottom).

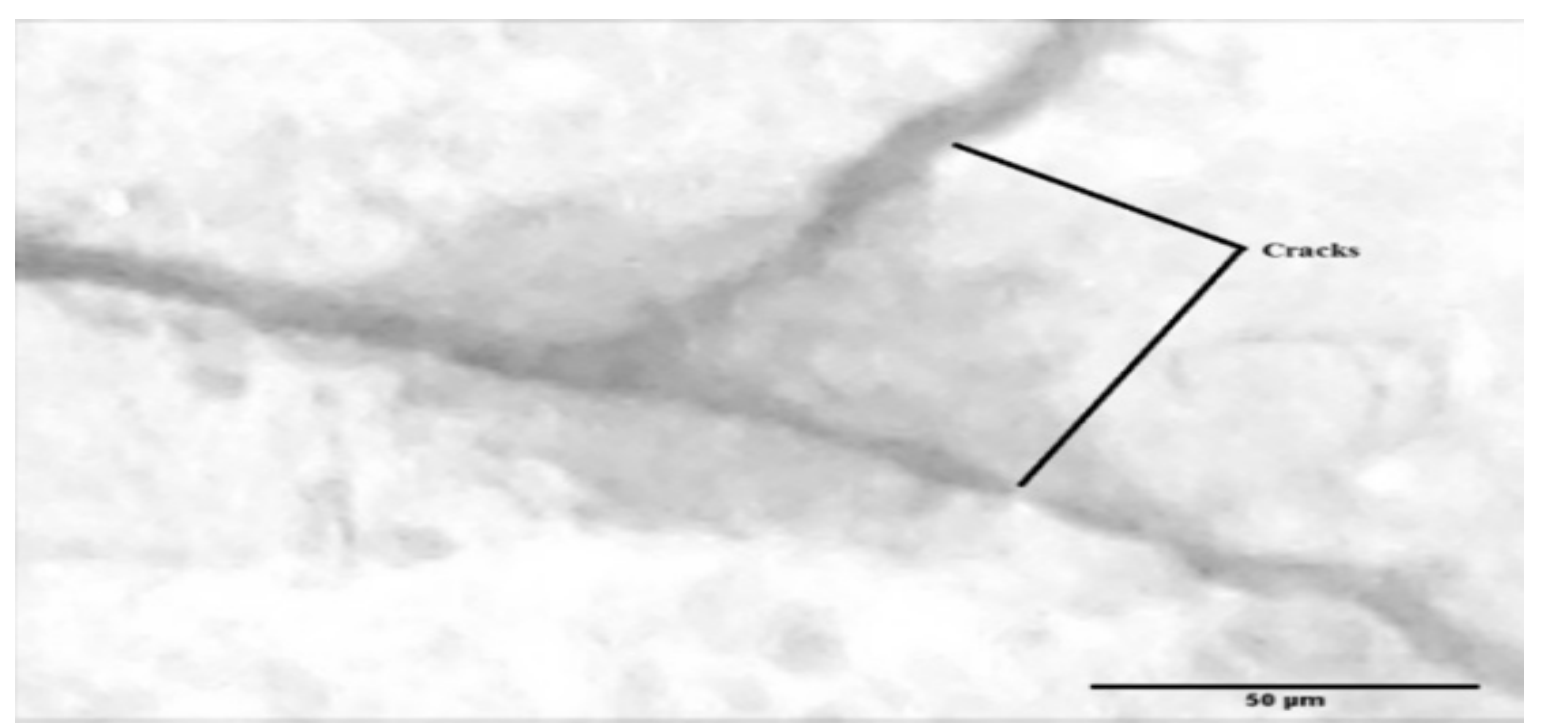

Figure 5. Optical microscope images of section of surface of reference bar after 84 days $(\times 40)$. 


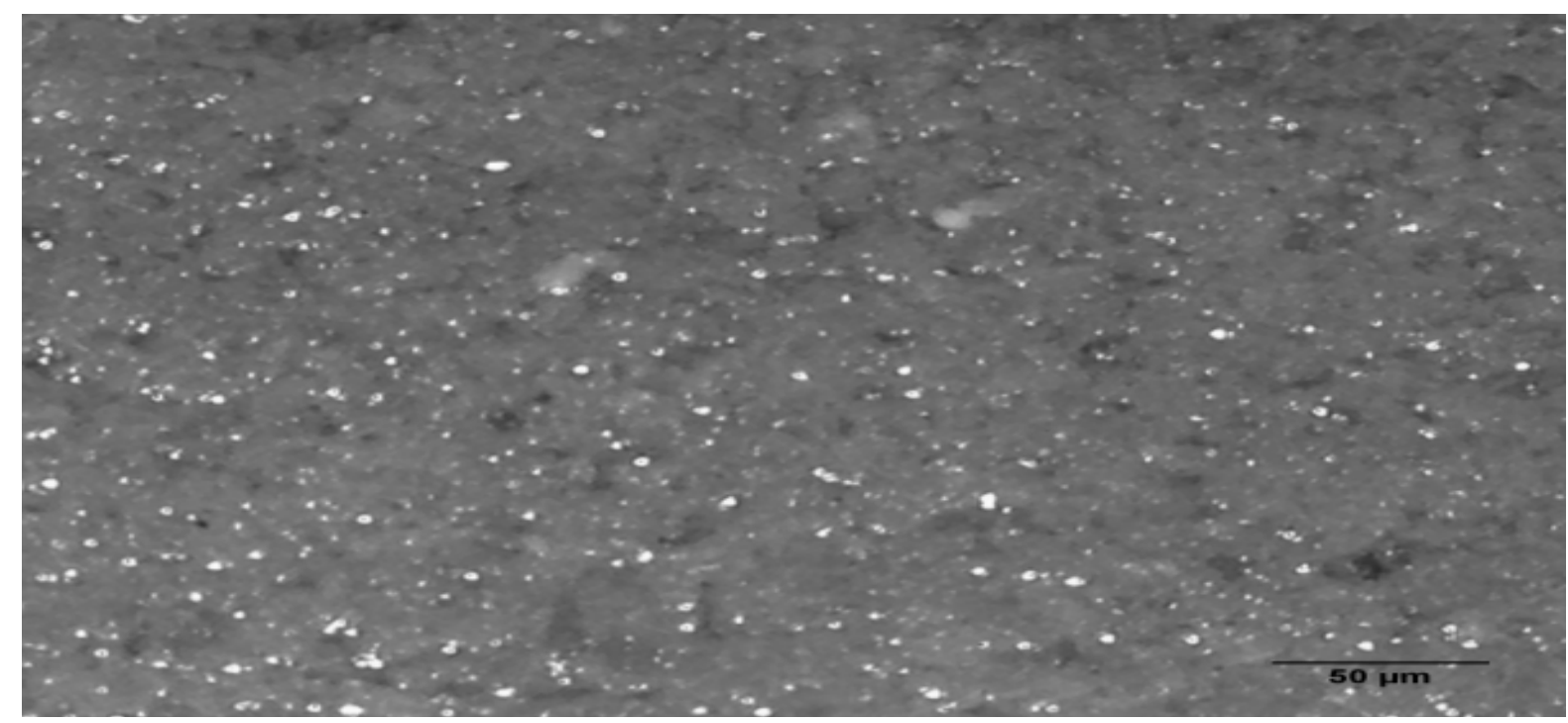

Figure 6. Optical microscope images of section of surface of sample containing 25\% pozzolan after 84 days $(\times 20)$.

calcined clay and the cement reaction resulted in a densification of the hardened paste which aided the containment of any possible expansive cracks. Hence the incidence of cracks on the surfaces of mortar bars containing pozzolan was reduced or even completely eliminated [13].

\section{Conclusions}

Calcined clay pozzolan has been shown in the study to have an influence on the alkali-silica reaction. As pozzolan content increased in the blended cement, expansion of mortar bars prepared from the cement decreased. The highest expansion at all ages of test was recorded by the reference with a maximum expansion of $0.35 \%$ after 42 days whilst the least expansion was obtained with mortar bars containing 25\% pozzolan.

Thus incorporation of $25 \%$ calcined clay pozzolan in mortar and concrete may be beneficial in mitigating ASR. Reaction products observed in hydrated samples incorporating pozzolan showed the formation of $\mathrm{CaSi}_{2} \mathrm{O}_{5}$ in increasing quantities and a decrease in the alkali silicate content as pozzolan content increased. The formation of the more stable $\mathrm{CaSi}_{2} \mathrm{O}_{5}$ and the decrease in the sodium silicate content is responsible for the lower expansion obtained with mortar bars containing pozzolan.

\section{References}

[1] American Society for Testing and Materials (2000) 2000 Annual Book of ASTM Standards: Part 14-C 150. Specification for ordinary Portland cement, ASTM, Philadelphia, 101-107.

[2] Multon, S., Sellier, A. and Cyr, M. (2009) Chemo-Mechanical Modeling for Prediction Of Alkali-Silica Reaction (ASR) Expansion. Cement and Concrete Research, 39, 490-500.

[3] Taylor, H.F.W. (1997) Cement Chemistry. 2nd Edition, Thomas Telford Publishing, London, 361. http://dx.doi.org/10.1680/cc.25929

[4] Sims, I. and Brown, B. (1998) Concrete Aggregates: Chapter 16 in Lea’s Chemistry of Cement and Concrete. 4th Edition, Elsevier, Oxford, 963.

[5] Tong, L. and Tang, M. (1999) Expansion Mechanism of Alkali-Dolomite and Alkali-Magnesite Reaction. Cement and Concrete Research, 21, 361-373. http://dx.doi.org/10.1016/S0958-9465(99)00022-0

[6] Malvar, L.J., Cline, G.D., Burke, D.F., Rollings, R., Sherman, T.W. and Greene, J. (2002) Alkali-Silica Reaction Mitigation: State-Of-The-Art and Recommendations. ACI Materials Journal, 99, 1-25.

[7] American Society for Testing and Materials (2000) 2000 Annual Book of ASTM Standards: Part 14-C 289. Standard Test Method for Potential Reactivity of Aggregates (Chemical Method), ASTM, Philadelphia, 187-195.

[8] American Society for Testing and Materials (2007) ASTM C 1260-07; Standard Test Method for Potential Reactivity of Aggregates (Mortar-Bar Method) ${ }^{1}$, ASTM, Philadelphia, 1-5.

[9] American Society for Testing and Materials (2008) ASTM C 1293-08; Standard Test Method for Determination of 
Length Change of Concrete Due to Alkali-Silica Reaction. ASTM, Philadelphia.

[10] Kandasamy, S. and Shehata, M.H (2014) Thecapacity of Ternary Blends Blends Containing Slag and High-Calcium Fly Ash to Mitigate Alkali Silica Reaction. Cement and Concrete Research, 49, 92-99. http://dx.doi.org/10.1016/j.cemconcomp.2013.12.008

[11] Canadian Standards Association (2009) CAN/CSA-A23.2-14A-09: Potential Expansivity of Aggregates; Procedure for Length Change Due to Alkali-Aggregate Reaction in Concrete Prisms. CSA, Ontario.

[12] Aquino, W., Lange, D.A. and Olek, J. (2001) The Influence of Metakaolin and Silica Fume on the Chemistry of Alkali-Silica Reaction Products. Cement and Concrete Research, 23, 485-493. http://dx.doi.org/10.1016/S0958-9465(00)00096-2

[13] Ramlochan, T., Thomas, M. and Gruber, K.A. (2000) The Effect of Metakaolin on Alkali-Silica Reaction in Concrete. Cement and Concrete Research, 30, 339-344. http://dx.doi.org/10.1016/S0008-8846(99)00261-6

[14] Turanli, L., Bektas, F. and Monteiro, P.J.M. (2003) Use of Ground Clay Brick as a Pozzolanic Material to Reduce the Alkali-Silica Reaction. Cement and Concrete Research, 33, 1539-1542. http://dx.doi.org/10.1016/S0008-8846(03)00101-7

[15] Karakurt, C. and Topçu, I.B. (2011) Effect of Blended Cements Produced with Natural Zeolite and Industrial By-Products on Alkali-Silica Reaction and Sulfate Resistance of Concrete. Construction and Building Materials, 25, 1789-1795. http://dx.doi.org/10.1016/j.conbuildmat.2010.11.087

[16] Walters, G.V. and Jones, T.R. (1991) Effect of Metakaolin on Alkali-Silica Reaction (ASR) in Concrete Manufactured with Reactive Aggregate. ACI Special Publication, 126, 941-954.

[17] Kostuch, J.A., Walters, G.V. and Jones, T.R (2003) High Performance Concrete Incorporating Metakaolin-A Review. Proceedings of the International Conference on Advances in Concrete and Structures: Concrete 2000, 17-19 September 2003, Xuzhou, 1799-1811.

[18] European Committee for Standardization (2000) European Standard EN 197-1, Composition, Specifications and Conformity Criteria for Common Cements. European Committee for Standardization, Brussels, 15.

[19] European Committee for Standardization (2002) European Standard EN 12620, Aggregates for Concrete. European Committee for Standardization, Brussels, 28.

[20] American Society for Testing and Materials (2000) 2000 Annual Book of ASTM Standards: Part 14-C33; Specification for Concrete Aggregate. ASTM, Philadelphia, 16.

[21] Wang, A.Q., Zhang, C.Z., Tang, M.S. and Zhang, N.S. (1999) ASR in Mortar Bars Containing Silica Glass in Combination with High Alkali and High Fly Ash Contents. Cement and Concrete Composites, 21, 375-381. http://dx.doi.org/10.1016/S0958-9465(99)00020-7

[22] Topçu, I.B., Boga, A.R. and Bilir, T (2008) Alkali-Silica Reactions of Mortars Produced by Using Waste Glass as Fine Aggregate and Admixtures such as Fly Ash and $\mathrm{Li}_{2} \mathrm{CO}_{3}$. Waste Management, 28, 878-884. http://dx.doi.org/10.1016/j.wasman.2007.04.005

[23] BSI (1990) British Standards 1377 (Part 2): Methods of Test for Soils for Civil Engineering Purposes—Classification Tests. BSI, London, 42.

[24] American Society for Testing and Materials (2000) 2000 Annual Book of ASTM Standards: Part 13-C 204; Standard Test Method for Fineness of Portland Cement by Air Permeability Method. ASTM, Philadelphia, 195-201.

[25] American Society for Testing and Materials (2000) 2000 Annual Book of ASTM Standards: Part 14-C 490; Standard Specification for Apparatus for Use in Measurement of Length Change of Hardened Cement Paste, Mortar and Concrete. ASTM, Philadelphia.

[26] American Society for Testing and Materials (2000) 2000 Annual Book of ASTM Standards: Part 14-C 618; Standard Specification for Fly Ash and Raw or Calcined Natural Pozzolana for Use as a Mineral Admixture in Portland Cement Concrete. ASTM, Philadelphia, 355-358.

[27] Ichikawa, T. (2009) Alkali-Silica Reaction, Pessimum Effects and Pozzolanic Effect. Cement and Concrete Research, 39, 716-726. http://dx.doi.org/10.1016/j.cemconres.2009.06.004 